\title{
A ENGENHARIA NOTURNA DE MÁRIO FAUSTINO EM O HOMEM E SUA HORA: LEITURA DO POEMA “MITO”
}

\author{
Luciano Cavalcanti *
}

RESUMO: Mário Faustino, poeta pertencente a geração de 1950, estabeleceu uma relação direta com a tradição moderna da poesia ocidental. Na qual percebe-se uma forte tendência à evasão do mundo ordinário e a importância do labor artesanal para a construção do poema. Nessa perspectiva, pretendemos, nesse estudo, dedicar nossos esforços na análise do poema "Mito", pertencente ao livro O homem e sua hora. Para tanto, será preciso observar a relação empreendida pelo poeta entre mito e poesia, como também o diálogo frutífero que Mário Faustino estabeleceu com o Surrealismo, uma das mais importantes tendências estéticas das vanguardas europeias do século XX.

PALAVRAS-CHAVE: Mário Faustino; Surrealismo; Mito

O sonho do poeta exige, numa camada mais profunda, a vigilia; e esta, por sua vez, acarreta $o$ abandono ao sonho.

Octavio Paz

\section{Introdução}

O Homem e sua hora (1955) foi o único livro publicado em vida por Mário Faustino. Dividido em três seções: "Disjecta membra", título retirado originalmente das Sátiras de 
Horácio: "Disjecti membra poetae”, que significa: "Os membros do poeta esquartejado”, composto por treze poemas predominantemente em versos decassílabos; "Sete sonetos de amor e morte", compostos à maneira inglesa - em uma única estrofe -, em decassílabos e "O homem e sua hora”, elaborado em um texto único, com 235 versos, em sua quase totalidade construídos em decassílabo. De acordo com Balestriero, o título desta obra está ligado ao próprio projeto poético de Faustino, o seu caráter atemporal, considerando que: “em O homem e sua hora, 'hora' tanto remete para as circunstâncias do homem Faustino, seu tempo presente, a hora presente, como pode ser igualmente considerada metaforicamente, hora não dada, abrangendo tempo não cronológico, sem dimensão estrita” (BALESTRIERO, 2011, p. 25). Nesse sentido, sua obra dará vazão ao sentimento universal do poeta tendo com preponderância a autonomia do signo verbal. Para o poeta a poesia é uma "arte poética", o que quer dizer que o poeta é um artesão que conhece os recursos próprios à construção poética e os utiliza de maneira eficiente representando o sentimento de seu tempo e de seu mundo.

Mário Faustino, poeta pertencente a geração de 1950, de alguma maneira, herdeiro da geração de 1945, estabeleceu uma relação direta com a tradição moderna da poesia ocidental. Na qual percebe-se uma forte tendência à evasão do mundo ordinário e a importância do labor artesanal para a construção do poema. Nesse sentido, sua poesia representará as contradições do mundo moderno e estabelecerá um diálogo frutífero com a poesia mais representativa desse período, por meio de autores como Rimbaud, Baudelaire, Valéry, Mallarmé, Rilke, Pound, Eliot e especificamente com os poemas longos da modernidade ${ }^{1}$,

\footnotetext{
${ }^{1}$ Nesse sentido, um grande poeta brasileiro que exercerá influência na poética de Faustino é Jorge de Lima, com seu monumental Invenção de Orfeu. Segundo Benedito Nunes: "Jorge de Lima, com sua Invenção de Orfeu, levou-o a fazer a aprendizagem da 'metáfora viva', projetada num plano cosmogônico, e a pensar numa aliança do lírico com o épico como dimensão de sua própria poesia. A imagística de O bomem e sua hora, em particular a dos sonetos, deve muito ao "Canto IV (Aparições)" da Invenção de Orfeu, (NUNES, 2002, p. 48) No que diz respeito a visada crítica do poeta piauiense, segundo Augusto de Campos, nas página que publicou sobre Jorge de Lima "encontraremos muita coisa que se poderia aplicar sobre sua própria poesia, em particular o que respeita ao projetado poema longo (...)" (CAMPOS, 1978, p. 43)
} 
etc. Há também um caráter singular na poesia de Faustino que deve ser levado em consideração, o seu diálogo com a tradição. Nessa perspectiva, pretendemos, nesse estudo, dedicar nossos esforços na análise do poema "Mito", pertencente a seção "Disjecta membra", de O homem e sua hora. Para tanto, será preciso observar a relação empreendida pelo poeta entre mito e poesia, como também o diálogo frutífero que Mário Faustino estabeleceu com o Surrealismo, uma das mais importantes tendências estéticas das vanguardas europeias do século XX.

A poesia moderna da metade do século XIX e meados do século XX se relacionará de maneira estreita ao onirismo. Para isso, ela não tratará descritivamente os seus assuntos, conduzindo-nos ao âmbito do não familiar, através de deformações e estranhezas. Dessa maneira, a lírica moderna trocará formalmente o vocabulário usual pelo insólito; a sintaxe desmembra-se ou reduz-se a expressões nominais intencionalmente primitivas, a metáfora e a comparação são aplicadas de uma maneira nova, forçando a união do que parece ser inconciliável.

Por estas características a poesia moderna se apresenta como de difícil compreensão, em que a surpresa e a estranheza se tornam seu conceito. Notoriamente é uma poesia que não satisfaz um leitor de hábitos fáceis. A interpretação possível desses textos segue “enfim, a pluralidade desses textos, na medida em que ela própria se insere no processo das tentativas de interpretação sempre poetizantes, inconclusas, conduzindo fora ao aberto" (FRIEDRICH, 1991, p. 19). Nesse sentido, a lírica moderna renuncia a ordem objetiva e a lógica para se colocar ao lado de outra característica marcante: a magia. Esta se apresenta no texto poético principalmente através de sua potencialidade sonora e dos "impulsos da palavra”, características estas que não caberiam na reflexão planejada.

A lírica moderna não almeja a cópia do real, mas sim a sua transformação. Para isso, o poeta utilizará do sonho e da fantasia, caminhos mais favoráveis para elevar sua capacidade criativa. Assim, a aspiração anterior à cópia é contraposta a fantasia e ao sonho, proporcionando o enriquecimento e aumentando imensamente a possibilidade criativa do artista moderno. Esse aspecto revela também, como ocorre com Rimbaud, segundo afirma 
Walter Benjamin, um tipo de atitude moderna da poesia que se apresenta como "respostas adequadas de uma consciência de criação às voltas com as inadequações de relacionamento entre poeta e sociedade" (BARBOSA, 1986, p. 19).

O surrealismo renovará a imagem poética utilizando-se desses recursos, principalmente se vinculando ao onirismo ${ }^{2}$. Comumente, na poética tradicional, a imagem tem como característico de sua construção a similitude entre seus termos de comparação. Na imagem surrealista, de forma contrária, sua formação (criação) se dá através da dessemelhança, ou seja, através da aproximação de duas realidades distantes. Desse modo, ao construir suas imagens os artistas surrealistas transgredem a ordem natural das comparações, provocando um choque intenso na sua linguagem - o que nos leva a percorrer os caminhos do sonho e da imaginação.

Max Ernest explica o procedimento que forma a imagem surrealista através das palavras de Lautréamont, que se tornou a definição da beleza surrealista: "Belo como o encontro casual de uma máquina de costura e um guarda-chuva sobre a mesa cirúrgica”.

Uma realidade acabada, cuja ingênua destinação parece ter sido fixada para sempre (o guarda-chuva), encontrando-se de repente a presença de outra realidade bastante diferente e não menos absurda (uma máquina de costura), num lugar onde ambas devem se sentir estranha (uma mesa cirúrgica), escapará, por isso mesmo, ao seu ingênuo destino e à sua identidade; ela passará do seu falso absoluto, pelo círculo em um relativo, a um absoluto novo, verdadeiro e poético: o guarda-chuva e a máquina de costura farão amor. O mecanismo do procedimento parece-me revelado por esse exemplo simplíssimo. A transformação completa, seguida por um ato puro como

${ }^{2}$ É especialmente a partir dos estudos de Freud sobre o sonho que os surrealistas tomaram contato com o mundo onírico. De acordo com a teoria freudiana, o sonho é constituído, principalmente, por dois elementos: o conteúdo manifesto (o que conseguimos contar) e o conteúdo latente (o que necessitamos decifrar para interpretar o sonho - é uma espécie de chave para compreendermos os significados do sonho) esse aspecto demonstra o motivo pelo qual encontramos dificuldades na compreensão dos sonhos. A sua caracterização básica encerra no sentido de que o sonho é sempre a realização de um desejo, mesmo que aparentemente se apresente de forma perturbadora ao sonhador. No seu sentido geral, as ideias essenciais do onirismo para Freud podem ser resumidas em duas palavras chaves: deslocamento e condensação, características essenciais da imagem poética. Essas duas formas conectivas típicas da imagem onírica correspondem a um princípio agregador e ou comparativo, próprios da metonímia e da metáfora. (Ver Freud, 2001) 
o do amor, produzir-se-á forçosamente todas às vezes que as condições serão tornadas favoráveis pelos fatos dados: acoplamento de duas realidades aparentemente inconciliáveis num plano que aparentemente não é conveniente para elas. (apud DE MICHELI, 1991, p. 161)

É a partir dessa perspectiva que a poesia moderna trabalhará a imagem em sua criação poética. Um exemplo claro disso pode ser notado nas palavras de um dos seus grandes representantes, o poeta-crítico Octavio Paz, quando caracteriza a imagem através da identidade de elementos contrários.

Épica, dramática ou lírica, condensada em uma frase ou desenvolvida em mil páginas, toda a imagem aproxima ou conjuga realidades opostas, indiferentes ou distanciadas entre si. Isto é, submete à unidade a pluralidade do real. Conceitos e leis científicas não pretendem outra coisa. (...) A imagem resulta escandalosa porque desafia o princípio de contradição: o pesado é o ligeiro. Ao enunciar a identidade dos contrários, atenta contra os fundamentos do nosso pensar. Portanto, a realidade poética da imagem não pode aspirar à verdade. $\mathrm{O}$ poema não diz o que é e sim o que poderia ser. Seu reino não é o do ser, mas o do "impossível verossímil" de Aristóteles. (PAZ, 1972, p. 38)

Na conjugação de elementos opostos também há o momento da convergência desses termos. Nessa ocasião, como nos diz o crítico, “... pedras e plumas, o leve e o pesado, nascer-se e morrer-se, serse, são uma e mesma coisa”. (PAZ, 1972, p. 42)3. Desse modo, a imagem poética funde elementos muitas vezes díspares numa espécie de renomeação e recriação do mundo de modo que o poeta, como no tempo primitivo, nomeia novamente as coisas. Como nos diz Octavio Paz “a imagem pode dizer o que, por natureza, a linguagem parece incapaz de dizer" (PAZ, 1972, p. 44). Outro ponto importante para o crítico

\footnotetext{
${ }^{3} \mathrm{~A}$ conciliação dos opostos aponta para "a identidade última entre o homem e o mundo, a consciência e o ser, o ser e a existência, é a crença mais antiga do homem e a raiz da ciência e da religião, magia e poesia. Todos os nossos empreendimentos se orientam para descobrir o velho caminho, a via esquecida da comunicação entre os dois mundos. Nossa busca tende a redescobrir ou a verificar a universal correspondência dos contrários, reflexo de sua original identidade." (PAZ, 1972, p. 42)
} 
diz respeito ao fato de que não precisamos recorrer a outras palavras para explicar a imagem, pois o seu sentido está nela mesma.

A imagem reconcilia contrários, mas esta reconciliação não pode ser explicada pelas palavras - exceto pelas da imagem, que já deixaram de sê-lo. Assim, a imagem é um recurso desesperado contra o silêncio que nos invade cada vez que tentamos exprimir a terrível experiência do que nos rodeia e de nós mesmos. O poema é linguagem em tensão: em extremo de ser em ser até o extremo. Extremos da palavra e palavras extremas, voltadas sobre a as suas próprias entranhas, mostrando o reverso da fala: o silêncio e a não significação. Mas aquém da imagem, jaz o mundo do idioma, das explicações e da história. Mais além, abrem-se as portas do real: significação e nãosignificação tornam-se termos equivalentes. Tal é o sentido último da imagem: ela mesma. (PAZ, 1972, p. 49)

Portanto, uma poesia imagética como esta, em que uma gama enorme de elementos que em épocas anteriores à modernidade raramente eram associados (relativamente presente em poucos poetas como Gongora, Baudelaire e Rimbaud - quero dizer, não era uma prática corrente na literatura), aumenta em muito a possibilidade criativa da utilização da metáfora pelos poetas modernos. No dizer de Hugo Friedrich, a metáfora é o "meio estilístico mais adequado à fantasia ilimitada da poesia moderna” (FRIEDRICH, 1991, p. 206), e ela não nasce da necessidade de reconduzir conceitos desconhecidos a conceitos conhecidos: "Realiza o grande salto da diversidade de seus elementos a uma unidade alcançável só no experimento da linguagem...”. (FRIEDRICH, 1991, p. 207) Nas palavras de Reverdy "a imagem é uma criação pura do espírito" e é "próprio da imagem forte ter nascido da aproximação espontânea de duas realidades muito distantes de que só o espírito percebeu as relações." (apud RAYMOND, 1997, p. 249) Nessa perspectiva, querer traduzi-las é o mesmo que matá-las.

\section{Leitura do poema "Mito"}

Mito

Os cães do sono ladram

Mas dorme a caravana do meu ser; 
Ser em forma de pássaro,

Sonora envergadura

Ruflando asas de ferro sobre o fim

Dos êxtases do espaço,

Cantando um canto de aço nos pomares

Onde o tempo não treme,

Onde frutos mecânicos

Rolam sobre sepulcros sem cadáver;

E sonho outros planaltos

Por mim sobrevoados na procela;

E sonho outras legendas

Em mim argamassadas pelo vento,

Trabalhadas em mim por mãos sem tato;

E sonho o que foi parco

Mas meu e por que raro perdido;

E sonho o que foi vasto

Mas de alheio me pesa sobre os ombros,

Globo de ásperos polos,

Continentes de medo

E mares onde o sangue é trilha e nódoa;

Deitado no vitral

Da noite intensa, exata,

Assim um Fazedor empunha o cetro

Ornado de serpentes;

Assim refaz o que foi feito à sua

Augusta semelhança

Contrafação de um gesto mais difícil

Sonâmbulo e remoto - contundente;

E enquanto nuvens quedam

De incenso carregadas, de semente,

Levanto-me e estrangulo

$\mathrm{O}$ ato de nascer que me divide

Em morna derrisão

Disforme difidência de um presságio;

O Fazedor anula

$\mathrm{O}$ inferno que o refina

E alçando-se ao poente mais seguro

Mergulha na verdade

Acesa que o derrota e reduz ao

Dormente ser de vidro e cor que sonha;

Os cães do sono calam 
E cai da caravana um corpo alado

E o verbo ruge em plena

Madrugada cruel de um albatroz

Zombado pelo sol -

(FAUSTINO, 2002, p. 90)

O poema nos leva, desde seu início, a uma "viagem" ao mundo do sono/sonho pela relação direta que estabelece com o mundo noturno, seja pelos vocábulos diretamente relacionados ao ambiente onírico: "sono", “dorme”, "sonho", "sonâmbulo”, "dormente” como também por sua construção imagética, que une elementos díspares na construção de suas imagens, tipicamente surrealistas. Uma faceta de grande importância, pois está intrinsecamente ligada a uma das técnicas fundamentais de sua obra poética: a montagem, como também a um certo misticismo, que o levou ao terreno da fantasia, do sonho e do insólito. Dessa maneira vemos por todo poema imagens inusitadas como: “Os cães do sono ladram", “[...] dorme a caravana do meu ser". "Ruflando asas de ferro sobre o fim”, “Cantando um canto de aço nos pomares", “[...] frutos mecânicos”, etc.

A presença do surrealismo com seu pressuposto básico da repulsa ao realismo positivista, que, para Breton, significava um empecilho a qualquer evolução intelectual e moral, prendendo o artista ao conhecido e ao classificável, empobrecendo o caráter imaginativo da arte que provém dos sentimentos é perfeitamente visível no poema de Mário Faustino. Para se afastar do "reino da lógica", que nos governa através do racionalismo fundamentado pela utilidade imediata e voltado para o senso comum, os surrealistas apontam as portas dos sonhos. Para estes, o onirismo possibilitaria uma ampliação do conhecimento por não estar preso estritamente ao racional. Nesse sentido, a imaginação ganha reconhecimento e garante o aprofundamento da mente, antes aprisionada pela racionalidade. Para Breton, é inaceitável que o onírico, parte tão importante da atividade psíquica, tenha chamado tão pouca atenção; o sonho e a noite não podem ficar reduzidos a um "parêntese".

Uma questão que chama atenção já no início do poema é a caracterização do eupoético em um "Ser em forma de pássaro", o que significa dizer que é um sujeito alado que 
habita as alturas, um novo ser, diferentemente do homem comum que vive no chão rasteiro, impedido de sonhar. Nesse sentido, poderíamos dizer que o poeta é um ser que alcança as alturas e, portanto, tem uma visão abrangente do mundo que o cerca. Por isso, mais ampla e arguta que o capacita a empreender uma nova ordem onírica, diferente da camada estéril da realidade. Esta visão ampliada desse ser permite que lhe seja revelado, por meio de sons exemplares, o apocalipse: "Sonora envergadura/ Ruflando asas de ferro sobre o fim".

Os cães do sono ladram

Mas dorme a caravana do meu ser;

Ser em forma de pássaro,

Sonora envergadura

Ruflando asas de ferro sobre o fim

É também perceptível a multiplicidade desse eu-lírico que se apresenta na “[...] caravana do meu ser;". Configuração característica do esfacelamento do eu (como enuncia a seção que o poema pertence: "Disjecta membra") no mundo moderno, que se desdobra em vários "eus" na tentativa de abarcar a multiplicidade de percepções desse mundo. Esta voz múltipla (fundidas no eu-poético que se torna vário) se configura com parte essencial na constituição de seu eu-lírico. É ela que se enuncia em sua poética, revelando o sujeito lírico como um cantor múltiplo: Orfeu, místico, sonhador, guia, herói, um defensor dos homens injustiçados e apequenados pelo mundo ordinário, que, inevitavelmente, nos remete as múltiplas máscaras heteronímias de Fernando Pessoa. É o que também ocorre com o ambiente temporal e espacial no poema, rompidos de maneira a reconfigurar a visão mimética desse mundo para uma perspectiva mítica:

Dos êxtases do espaço,

Cantando um canto de aço nos pomares

Onde o tempo não treme,

Dessa maneira, Faustino associa a poesia à dimensão mítica, no sentido de que uma das fortes marcas da natureza literária, como a do mito, é promover o encontro do indivíduo com a memória profunda (anamnese) da cultura. Situação que permite ao homem pensar 
sua vivência individual e coletiva e questionar tanto o seu próprio destino, como o da humanidade. Nessa perspectiva, o mito e a literatura vão conceber o tempo e o espaço de modo semelhante. O tempo mítico consiste na competência de resgatar o passado, revocálo. O mito através das formas culturais, especialmente artístico-literária, expressa o desejo humano de suplantar o tempo e o espaço, que no mito se revela tanto nas formas culturais "primitivas" como nas modernas e atuais. No espaço mítico, a literatura pode chegar a lugares impossíveis, podendo se configurar por um modelo simbólico, nos remetendo a um lugar ancestral da cultura.

Nesse sentido, o tempo, no poema, se relacionará de maneira estreita ao mito. O tempo mítico consiste, justamente, na competência poética de resgatar do passado, de revocá-lo, abolindo a distância. Desse modo, como aponta Eliade, sentimos na literatura, de maneira mais intensa que em outras expressões artísticas, o anseio de atingir um tempo diferenciado daquele que somos "obrigados a viver e trabalhar" revelando que o homem moderno preserva, ainda que pouco, um "comportamento mitológico". Os traços de tal comportamento "revelam-se igualmente no desejo de reencontrar a intensidade com que se viveu, ou conheceu, uma coisa pela primeira vez; de recuperar o passado longínquo, a época beatífica do "princípio"”. (ELIADE, 1998, p. 164-165)

No espaço mítico, pela poesia, pode-se gerar um lugar excepcional, pois nesse ambiente diferenciado do real não contam mais as impossibilidades físicas. O espaço pode se realizar, nesse momento, por meio de um modelo simbólico que nos remeta a variados topos da nossa cultura ancestral. Essas condições também nos revelam o caráter utópico empreendido pelo poeta, já que a apresentação do espaço de maneira diferenciada da concepção tradicional alcança um redimensionamento, no qual se pode esperar por relações imprevistas e encontros paradoxais. É o que ocorre também em relação ao redimensionamento do tempo, que é “reescrito”, não por meio da convenção cronológica e linear, mas através da memória, da fantasia e do sonho.

É nessa perspectiva que o eu-lírico dá sequência ao poema, na expressão da busca de um mundo, reconfigurado, diferente do presente: 
E sonho outros planaltos

Por mim sobrevoados na procela;

E sonho outras legendas".

Em mim argamassadas pelo vento,

Trabalhadas em mim por mãos sem tato;

E sonho o que foi parco

Mas meu e por que raro perdido;

O que vemos aqui é a associação do texto literário à dimensão mítica, o poema busca uma espécie de "memória profunda" da cultura, trazendo para o presente um passado mítico perfeito. Nessa perspectiva o poeta vivenciará os momentos do mundo primeiro pela poesia. Aspecto visível não só por seu anseio de enunciar uma vida diferente da do presente, como retornar a um passado perdido, mas também pelo próprio ritmo do poema entregue à inspiração, livre de quaisquer amarras e por suas imagens. O poeta busca atingir as camadas mais profundas do ser através da correspondência entre o mundo edênico do passado mítico e seu poema.

O desejo de volta ao tempo das origens impulsionará o poeta ao redimensionamento da linguagem vivenciada por ele no tempo presente. Para isso o poeta estabelecerá um diálogo frutífero com o sonho. O que naturalmente nos leva a relacionar a poesia de Faustino ao Surrealismo. A presença do surrealismo com seu pressuposto básico da repulsa ao realismo positivista, que, para Breton, significava um empecilho a qualquer evolução intelectual e moral, prendendo o artista ao conhecido e ao classificável, empobrecendo o caráter imaginativo da arte que provém dos sentimentos, é perfeitamente visível nos versos do poema. Para se afastar do "reino da lógica", que nos governa através do racionalismo fundamentado pela utilidade imediata e voltado para o senso comum, os surrealistas apontam as portas dos sonhos.

O poema parece anunciar, de forma simbólica, o desejo da conquista do mundo anterior à Queda, pelo verbo. A criação desse "mundo/poesia" almejado pelo poeta se dá não apenas pela referência a um ambiente paradisíaco, mas através do verbo, refletindo este ambiente na busca da palavra desse tempo. Isto é, metaforicamente, do momento da nomeação das coisas, da palavra dita pela primeira vez, poética pela carga de novidade trazida, 
seja em sua sonoridade, seja em seu significado metafórico. O poeta buscará trazer de volta este sentido "primitivo" da palavra por meio da renovação de sua linguagem, através da renovação da metáfora ou por meio da busca de uma linguagem mítica, pois o conhecimento racional apresenta-se inadequado e/ou insuficiente e não tem o alcance que o pensamento subjetivo oferece. É somente por esta perspectiva que o poeta pode almejar a reconstrução da linguagem perdida do início dos tempos. Desse modo, ele rompe com o tempo e com o espaço, podendo reiniciar o mundo por meio de um imaginário do passado original, que é motivo de satisfação e alegria, pois o tempo primordial reconquistado e o novo ambiente é profícuo para a criação ${ }^{4}$.

Para Mielietinsky (1987), no século XX, ocorre o fenômeno da "mitologização" da literatura quer como "fenômeno artístico" quer como "visão de mundo" diretamente relacionado ao seu tempo que presenciou revoluções, guerras e massacres que mudaram substancialmente a história da humanidade abalando toda sua estrutura social. É por isso, nesse "caos", que a literatura busca o "cosmos" revitalizador da ordem. Para isso, a literatura necessitou superar os limites "histórico-sociais" e "espaços-temporais" o que acarretou a ela um redimensionamento do tempo e do espaço, anteriormente presos à verossimilhança da representação do real. Nesse momento, a literatura, através do mito, utilizou-se da fantasia e do simbólico para ajustar sua linguagem ao tempo presente.

Ernest Cassirer aponta para o alto poder da palavra no universo mítico das cosmogonias, chegando mesmo a ser comparada ao poder dos deuses, ou mesmo, maior que

\footnotetext{
${ }^{4}$ Isso ocorre no dizer de Raymond porque "O poeta não reconhece mais os quadros que o universo sensível desenrola em seus olhos; eles lhe parecem tão anormais, tão estranhos quanto a mais extraordinária das fantasmagorias. Em contrapartida, os acontecimentos que se constroem nele impõem-se a seu olhar interior com uma força concreta que obriga às vezes a por em dúvida todo o resto; aquelas coisas que consideramos "imaginárias" não são verdadeiras evidências? "O mundo é um sonho e o sonho é um mundo", segundo a fórmula dos românticos alemães. Entre os fatos da vida interior e os da vida exterior, sinais respondem aos sinais; uma unidade oculta na qual desapareceriam todos os objetos e todos os seres, deixa-se pouco a pouco apreender além dos fenômenos que solicitam os sentidos e além das imagens que compõem os sonhos. Suposto entre os dois mundos o poeta, em um semi-êxtase, avança para o centro da realidade.” (RAYMOND, 1997, p. 194)
} 
eles. Ao analisar a relação entre linguagem e mito, o teórico assinala a possível origem comum da consciência mítica à consciência linguística no sentido de que ambas as linguagens assentam-se na mesma concepção mental: o pensamento metafórico.

\begin{abstract}
A linguagem e o mito se acham originalmente em correlação indissolúvel, da qual só aos poucos cada um se vai despendendo como membro independente. Ambos são ramos diversos da mesma enformação simbólica, que brota de um mesmo ato fundamental, e da elaboração espiritual, da concentração e elevação da simples percepção sensorial. Nos fonemas da linguagem, assim como nas primitivas configurações míticas, consuma-se o mesmo processo interior; ambos constituem a resolução de uma tensão interna, a representação de moções e comoções anímicas em determinadas formações e conformações objetivas. (CASSIRER, 1985, p. 106)
\end{abstract}

Desse modo, como as metáforas, o mito exerce a função de fazer falar os níveis mais profundos do ser humano. Por meio da expressão simbólica o homem pode vislumbrar seus questionamentos mais íntimos, que também são universais.

Este mecanismo de fazer falar o incognoscível, desejo do homem de todos os tempos, se realiza plenamente na criação artística. Mas, o mais importante para expressão literária não é a ideia de que os mitos são metáforas do comportamento humano, mas o modo que a linguagem será trabalhada pelo escritor, por meio da elaboração de metáforas e imagens que busquem o conhecimento original, na tentativa de expressar em "verbo" um tipo de conhecimento que é oculto aos homens. É também por causa desse desejo, intrínseco ao homem, que uma grande parte da literatura moderna procurou recuperar a visão mítica na criação artística, utilizando-a como uma espécie de suporte para adentrar nas zonas mais conflitantes e obscuras do homem desse tempo. Em um mundo caracteristicamente fragmentado e complexo os artistas aspiram, por meio da visão mítica, a reconquista da unidade perdida.

Dessa forma, a linguagem poética não se limitará apenas a um papel comunicativo. Ela supera esse caráter pragmático, utilitário que deseja contar algo. Ela quer reviver a experiência primeira da nomeação das coisas do mundo, como nos primórdios. Esta experiência é essencialmente poética, inaugural e anuncia um novo mundo, ilumina o mundo 
sombrio em que vivemos e anuncia um mundo extraordinário e que contém uma "plenitude inacessível". Este narrar inaugural é poiesis, fundação de um novo mundo. "A palavra originário significa fazer eclodir algo, trazer algo ao ser num salto fundador, a partir da proveniência da essência” (HEIDEGGER, 2010, p. 199). Desse modo, para Heidegger, em um sentido essencial, a própria linguagem é poiesis.

Mas porque a linguagem é aquele acontecimento no qual, a cada vez, o sendo como sendo se abre pela primeira vez para o ser humano, por isso é a poesia, a poiesis em sentido mais restrito, a mais originária poiesis em sentido essencial. A linguagem não é por isso poiesis, ou seja, porque é a poesia primordial, mas a poesia apropria-se na linguagem, porque esta conserva a essência originária da poiesis. (HEIDEGGER, 2010, p. 189)

Para Heidegger, inversamente do que se poderia pensar, a linguagem possui o homem e não o contrário. E este só se realiza enquanto tal pela linguagem, pois “a linguagem é a morada do ser". No entanto, o homem, no cotidiano, inverte essa relação. De modo que ele passa a usar a linguagem em vez de deixar-se manifestar por ela. Dessa maneira, o sentido original da palavra é ocultado e sua poesia desaparece. Para o filósofo, só a linguagem poética é capaz de desautomatizar a palavra de seu uso banal e fazer reaparecer sua originalidade. Nesse sentido, podemos dizer que a linguagem poética e/ou original, como concebida por Heidegger, se assemelha ao mito, concebido como origem, pois o mito também funda/cria um mundo como qualquer obra de arte.

O desejo de fuga do mundo presente vivenciado pelo poeta ocorre porque o mundo está em tormenta e o poeta, transfigurado na figura mítica de Atlas ${ }^{5}$, não pode mais sustentar. A multiplicidade ou a transmutação do eu-poético é fortemente marcada no poema que

\footnotetext{
${ }^{5} \mathrm{Na}$ mitologia grega Atlas se juntou aos outros Titãs, quer eram forças da desordem e também do caos, com a finalidade de conseguir o poder supremo do mundo. A ideia era atacar o Olimpo, travando um combate com Zeus e todos os seus defensores que, por sua vez, eram forças do cosmo e da Ordem. Ele participou ativamente da batalha que ficou conhecida como Titanomaquia. O que aconteceu foi que nessa batalha, o triunfo foi de Zeus e dos deuses do Olimpo. Como punição aos perdedores Zeus enviou todos os Titãs para o Tártaro, com exceção de Atlas, para o qual preparou um castigo especial. Nesse castigo Zeus determinou que os derrotados seriam eternos escravos dos sentidos e da matéria, tornando-se a antítese da espiritualização. Para Atlas então, ficou o castigo de 
chega a ser vislumbrado em um vitral (tipo de vidraça composta por pedaços de vidro coloridos ou pinturas sobre o vidro) e/ou um mosaico. O que revela que a figuração do poeta é composta por vários pedaços, que juntos revelam um ser composto pela multiplicidade de vários fragmentos, ou outros eus. É interessante notar que é dessa mesma maneira que o eu-lírico elabora as imagens de seu poema, construídas por vários fragmentos. Este sujeito criador que usa um cajado que simboliza poder de comando, provavelmente Moisés, que usava um cajado que se transformava em serpente para manifestar a cólera de Javé, colorindo o Nilo de sangue, separando as águas do mar Vermelho, traz para o poema um caráter escatológico e também de escárnio à própria vida.

E sonho o que foi vasto

Mas de alheio me pesa sobre os ombros,

Globo de ásperos polos,

Continentes de medo

E mares onde o sangue é trilha e nódoa;

Deitado no vitral

Da noite intensa, exata,

Assim um Fazedor empunha o cetro

Ornado de serpentes;

Assim refaz o que foi feito à sua

Augusta semelhança

Contrafação de um gesto mais difícil

Sonâmbulo e remoto - contundente;

E enquanto nuvens quedam

De incenso carregadas, de semente,

Levanto-me e estrangulo

$\mathrm{O}$ ato de nascer que me divide

Em morna derrisão

Disforme difidência de um presságio;

O Fazedor anula

$\mathrm{O}$ inferno que o refina

E alçando-se ao poente mais seguro

Mergulha na verdade 
Acesa que o derrota e reduz ao

Dormente ser de vidro e cor que sonha;

O mundo atravessa inúmeras tormentas causadas pelas guerras, sofrimentos, injustiças, mecanização do indivíduo, destruições, etc. Podemos estabelecer uma relação deste fragmento ao momento histórico do pós-guerra (década de 40), anterior à feitura do poema, em que os regimes totalitários e as guerras causaram sofrimentos, perseguições e mortes. Mário Faustino compõe seu poema em um momento histórico extremamente delicado para o mundo e, nesse sentido, o poema, apresenta ao leitor através de uma série de imagens perturbadoras um retrato do tempo presente. É contra este cenário que o poema se rebela e busca transcender e recriar o mundo e a poesia. Dessa forma, Mário Faustino mostra a situação perturbadora em que se encontra o homem moderno (do século XX), com a presença de duas grandes guerras mundiais. Nesse mundo conturbado e ameaçador o homem vive em conflito não só com a sociedade, mas com ele mesmo, marcando também o conflito com as instituições guardiãs desses valores sociais: a Igreja, o Estado, a Família, etc. Numa constante "evolução" o mundo se mostra ao homem através de grandes modificações de valores e conceitos, a ciência passa a reavaliar suas teorias, regimes políticos com forte caráter ideológicos se firmam (em combates vigorosos) e cometem atrocidades, o avanço da técnica e o automatismo contribuem para despersonalização do homem. Nesse sentido, Faustino canta o homem (herói) moderno que vive um drama apocalíptico e deseja recompô-lo ao tempo original na tentativa de resgatar valores primordiais ${ }^{6}$.

É o que reafirma a sequência do poema, com a queda do homem em um mundo desprovido de poesia. Onde o poeta em seu exercício de criação "ruge" (fala em voz alta

\footnotetext{
${ }^{6}$ Poucos poetas conseguiram enfrentar esta tarefa e conseguir êxito, caso exemplar em nossa literatura é o de Carlos Drummond de Andrade com A Rosa do povo, de 1947. Num período próximo a feitura desses versos importantes poetas brasileiros, como o próprio Drummond ("Carta a Stalingrado"), Cecília Meireles ("Jornal, Longe”), Murilo Mendes (“Aproximação do Terror"), Jorge de Lima (Invenção de Orfeu), entre outros, também estavam escrevendo poemas relacionados ao contexto histórico-social da época, em que ocorriam mortes, massacres e destruição por causa da Segunda Guerra Mundial. Mário Faustino soma-se a estas vozes no sentido de repudiar, em sua poesia, os acontecimentos históricos recentes. Esse aspecto é também demonstrado pela tentativa de "reencantar" o mundo, no sentido de que o poeta pretende fazer sobreviver a poesia no mundo moderno.
} 
ou com raiva), revela os desmandos do mundo e é motivo de sarcasmo, como aponta a referência ao albatroz baudelairiano. Enfim, o poema aponta para a realização poética pelo sonho, que possibilita a manifestação do poético contraposto ao mundo ordinário, estéril e desencantado da modernidade.

\author{
Os cães do sono calam \\ E cai da caravana um corpo alado \\ E o verbo ruge em plena \\ Madrugada cruel de um albatroz \\ Zombado pelo sol -
}

\title{
Considerações finais
}

Como vimos, a expressão poética de Mário Faustino pode ser notada de maneira privilegiada em dois principais modos: o noturno e o mítico. O primeiro liga o procedimento poético do autor ao onirismo, como é característico da estética surrealista, a partir dos seus diversos desdobramentos: na utilização da colagem, na metáfora construída por meio de associações de elementos díspares, na utilização mesma do sonho como elemento que propicia o impulso poético e também do imaginário noturno.

A expressão onírica ganha um sentido profundo em sua poética, pois corresponde à própria concepção do "fazer poético", que se atém à inspiração para criação de seus poemas, mas não no sentido simplista de deixar o "correr da pena" sem que haja o apuro da linguagem. O exercício poético também está intrinsecamente ligado ao controle de sua criação, mesmo o poeta se utilizando de forma privilegiada do imaginário. É como nos diz de Octavio Paz: "O sonho do poeta exige, numa camada mais profunda, a vigília; e esta, por sua vez, acarreta o abandono ao sonho.” (PAZ, 1982, p. 202)

No segundo modo, Mário Faustino utiliza-se do mito. O que revela o desejo do poeta de retornar à inocência, à pureza e ao tempo original. Em uma espécie de sonho com a existência primordial, o poeta se afasta do tempo presente devastado pelas contingencias de sua modernização. Dessa forma, sua lírica se voltará para o mito, para o escatológico e para o mistério da criação poética. Os mitos são fontes de inspiração, assim como as fantasias e criações imaginárias dos sonhos são também estímulos à sua atividade artística. 


\section{MÁRIO FAUSTINO NIGHT ENGINEERING IN O HOMEM E SUA HORA, READING THE POEM "MITO"}

ABSTRACT: Mário Faustino, poet in the generation of 1950, established a direct relationship with the modern tradition of Western poetry. In which we see a strong trend to circumvention of the ordinary world and the importance of artisanal labor to the construction of the poem. In this perspective, we in this study, dedicate our efforts on analyzing the poem "Mito", in the book O homem $e$ sua hora. To do so, you must observe the relationship undertaken by the poet between myth and poetry, as well as the fruitful dialogue that Mario Faustino established with surrealism, one of the most important aesthetic trends of the European avant-garde of the XX century.

KEYWORDS: Mario Faustino; Surrealism; Myth

\section{REFERÊNCIAS}

BARBIERI, Ivo. Oficina da palavra. Rio de Janeiro: Achimé, 1979.

BARBOSA, João Alexandre. As ilusões da modernidade. São Paulo: Perspectiva, 1986.

BELESTRIERO, Maria Lúcia Gonçalves. Mário Faustino: uma poética da modernidade. São Paulo, Editora Unesp, 2011.

BOAVENTURA, Maria Eugênia. Um militante da poesia. In: FAUSTINO, Mário. O homem e sua hora e outros poemas. (Org. BOAVENTURA, Maria Eugênia). São Paulo: Cia das Letras, 2002.

BRETON, André. Manifestos do Surrealismo. (Trad.: Sérgio Pachá) Rio de Janeiro: Nau Editora, 2001.

CAMPOS, Augusto. Mário Faustino, o último “verse maker". In: Poesia, antipoesia, antropofagia. São Paulo: Cortez \& Moraes, 1978.

CAMPOS, Haroldo. Mário Faustino ou a impaciência órfica. In: Metalinguagem e outras metas: ensaios de teoria e crítica literária. São Paulo: Perspectiva, 2006.

CASSIRER, Ernst. Linguagem e mito. São Paulo: Perspectiva, 1989.

DE MICHELI, Mário. Sonho e realidade do Surrealismo. In: As vanguardas artísticas do século XX. São Paulo: Martins, 1991.

ELIADE, Mircea. Mito e realidade. São Paulo: Ed. Perspectiva, 1998.

FAUSTINO, Mário. O homem e sua hora e outros poemas. (Org. BOAVENTURA, Maria Eugênia). São Paulo: Cia das Letras, 2002.

FREUD, Sigmund. A interpretação dos sonhos. Rio de Janeiro: Imago, 2001. 
FRIEDRICH, Hugo. Estrutura da lírica moderna: problemas atuais e suas fontes. São Paulo: Duas Cidades, 1991.

HEIDEGGER, Martin. A origem da obra de arte. (Trad. Idalina Azevedo e Manuel A. de Castro) São Paulo: Edições 70, 2010.

MIELIETINSKI, E. M. A poética do mito. Rio de Janeiro: Forense - Universitária, 1987.

NUNES, Benedito. A poesia de meu amigo Mário. In: FAUSTINO, Mário. O homem e sua hora e outros poemas. (Org. BOAVENTURA, Maria Eugênia). São Paulo: Cia. das Letras, 2002.

PAZ, Octavio. A inspiração. In: O Arco e a lira. Rio de Janeiro: Nova Fronteira, 1982. . Signos em rotação. São Paulo: Perspectiva, 1972.

RAYMOND, Marcel. De Baudelaire ao surrealismo. São Paulo: EDUSP, 1997.

Recebido em: 2/06/2019. Aprovado em: 31/07/2019. 